\title{
Nutrient Optimization for Improved in vitro Plant Regeneration in Eclipta alba (L.) Hassk. and Assessment of Genetic Fidelity using RAPD Analysis
}

\section{Shruti Bardar, Varsha Khurana-Kaul, Sumita Kachhwaha and \\ S.L. Kothari*}

Department of Botany, University of Rajasthan, Jaipur, India-302 004

Key words: Eclipta alba, Genetic fidelity, RAPD analysis

\begin{abstract}
This study highlights the effect of different inorganic micronutrients like copper, cobalt, molybdenum, zinc, boron, iodine, iron and manganese in accelerating and amplifying in vitro shoot bud induction and proliferation of a medicinally important plant, Eclipta alba (L.) Hassk. Direct shoot bud induction was observed on MS fortified with $\mathrm{Kn}(2 \mathrm{mg} / \mathrm{l})$. However, maximum number of shoots was achieved when $\mathrm{GA}_{3}, 0.5 \mathrm{mg} / \mathrm{l}$ was added to induction medium along with $1 \mu \mathrm{M}$ copper sulphate (ten times the normal MS level). Optimization of nutrient level in the basal medium promoted maximum regeneration response from both shoot tips and nodal explants. Elongated shoots were rooted in MS supplemented with IBA, $1.0 \mathrm{mg} / \mathrm{l}$. Healthy, green plantlets with well developed roots, flowered normally in the field. Genetic stability of micropropagated plantlets was evaluated using RAPD markers. The amplification products were monomorphic in micropropagated plantlets and similar to those of mother plant revealing the genetic uniformity of plantlets. The regeneration protocol is highly efficient and reproducible so would be useful for mass multiplication, ex situ conservation and genetic transformation of E. alba (L.) Hassk.
\end{abstract}

\section{Introduction}

Annual herbaceous plant Eclipta alba (L.) Hassk. [synonym- Eclipta prostrata (Linn.), family: Asteraceae] native to tropics and subtropics during rainy season, is popularly known as 'False Daisy' or 'Bhringraj' and has tremendous medicinal importance since ancient times. Apart from blackening and promoting hair growth; antiageing, hepatoprotective, antihyperglycemic, antidiabetic, antiinflammatory, antioxidant and antimicrobial activities of the plant have also been

*Author for correspondence: <slkothari@lycos.com>. 
well documented (Jadhav et al. 2009). Pharmacological investigations have elucidated association of hepatoprotective property mainly due to two active constituents; wedelolactone and desmethylwedelolactone (Franca et al. 1995).

Although, there are several reports on in vitro plant regeneration of this medicinally important plant (Franca et al. 1995, Borthakur et al. 2000, Gawde and Paratkar 2004, Dhaka and Kothari 2005, Ray and Bhattacharya 2008, Singh et al. 2012) but attempts have not been made to standardize nutrient requirement to improve regeneration. As, the nutrient requirement of the cultured tissue may vary according to different stages of explant growth and development so an understanding of optimal nutrient concentration in the culture medium could lead to increase growth and evoke efficient in vitro morphogenesis. Considering the above facts, the present study was undertaken to optimize the levels of inorganic micronutrients viz. copper, cobalt, molybdenum, zinc, boron, iodine, iron and manganese to improve the regeneration potential of E. alba and to highlight their individual role in accelerating and amplifying the in vitro shoot bud induction and proliferation.

Plant cell culture results in high frequency of variation in regenerated plants (Larkin and Scowcroft 1981). Therefore, proper evaluation of genetic uniformity of regenerants with that of the mother plant for upholding desired traits is critically needed. To fulfill this purpose, molecular markers such as RAPD is widely employed as it is quick, simple, reliable, cost effective and requires only small amounts of DNA (Goyal et al. 2012). So the current study also inculcates RAPD analysis for evaluating genetic stability of the in vitro raised plantlets.

\section{Materials and Methods}

Young healthy plants of Eclipta alba were collected from the National Institute of Ayurveda, Jaipur, India and further grown in the botanical garden of University of Rajasthan, Jaipur. Nodal segments $(0.5-1.0 \mathrm{~cm})$ and shoot tips $(0.2-0.5 \mathrm{~cm})$ were excised from young healthy branches, rinsed in $20 \%(\mathrm{v} / \mathrm{v})$ 'Extran' (liquid detergent; Merck, India) for 3 to 5 min and washed with running tap water for half an hour, immersed in $0.1 \%$ aqueous $\mathrm{HgCl}_{2}$ solution for 4 to $5 \mathrm{~min}$, and finally washed in autoclaved distilled water five times. Since the use of sodium hypochlorite did not prevent contamination, mercuric chloride was used as surface sterilizing agent throughout the experiment.

Shoot tips and nodal segments were cultured in $100 \mathrm{ml}$ Erlenmeyer flasks containing $40 \mathrm{ml}$ MS supplemented with $0.8 \%$ agar (Merck, Bacteriological Grade) and $3 \%(\mathrm{w} / \mathrm{v})$ sucrose. The $\mathrm{pH}$ of the medium was adjusted to 5.8 prior to autoclaving at $121^{\circ} \mathrm{C}$ and $1.2-1.3 \mathrm{~kg} \mathrm{~cm}^{-2}$ pressure for $20 \mathrm{~min}$. All cultures were 
maintained at $26 \pm 1{ }^{\circ} \mathrm{C}$ with a photoperiod of $16 \mathrm{hrs}$ provided by white fluorescent tubes and incandescent bulbs ( $40 \mathrm{~W}$, Philips, India).

Shoot tips and nodal segments were cultured separately on MS containing various cytokinins: $\mathrm{Kn}(0.5$ - $5.0 \mathrm{mg} / \mathrm{l}), \mathrm{BAP}(0.5-5.0 \mathrm{mg} / \mathrm{l})$ or TDZ (0.1 - $2.0 \mathrm{mg} / \mathrm{l})$, $3 \%$ sucrose and $0.8 \%$ agar. After 15 - 20 days, the cluster of shoot buds proliferated in primary cultures was sectored and transferred onto proliferation medium supplemented with varying concentrations of $\mathrm{Kn}(0.5-5.0 \mathrm{mg} / \mathrm{l})$ in combination with GA3 $(0.1-3 \mathrm{mg} / \mathrm{l})$. Healthy green shoots $(>2 \mathrm{~cm})$ were transferred to rooting medium and smaller ones were subcultured for further proliferation. Shoot tips and nodal segments of in vitro elongated shoots were also used as explants. Each treatment consisted of six replicates and the experimental unit was four explants per flask.

In another set of experiments, MS supplemented with $\mathrm{Kn}(2 \mathrm{mg} / \mathrm{l})$ was modified with different concentrations of cobalt chloride (up to 50×), manganese

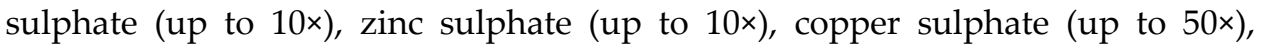
sodium molybdate (up to 50×), potassium iodide (up to $5 \times$ ), boric acid (up to 10×), iron disodium ethylene diaminotetracetic acid (up to $5 \times$ ), one nutrient at a time, to study the effect of a particular nutrient on shoot bud induction from shoot tips and nodal segments. After 3 weeks of culture, all the shoot buds were transferred to the medium with a modified concentration of a particular nutrient used in the induction medium.

Individual young healthy shoots $(>2 \mathrm{~cm})$, obtained at the end of 30 days, were excised from shoot clusters and transferred to MS and half MS containing $3 \%(\mathrm{w} / \mathrm{v})$ sucrose, $0.8 \%(\mathrm{w} / \mathrm{v})$ agar and supplemented with $0.5-2.0 \mathrm{mg} / \mathrm{l}$ each of IBA, IAA, phenylacetic acid (PAA) and NAA individually.

The plantlets with well developed roots obtained after 20 days of culture on rooting media were removed from cultures, washed gently under running tap water and transferred to earthen pots containing mixture of farmyard manure, autoclaved garden soil and sand $(1: 2: 1)$. The pots were covered with porous polythene bags for maintaining humidity and irrigated every fourth day with one-eighth strength MS basal salt solution devoid of sucrose for 2 weeks. The relative humidity was reduced gradually, and after 15 days of acclimatization the plantlets were transferred to field conditions and kept under shade in a net house for further growth and development. The morphological characteristics, growth parameters and floral features were examined. After 2 weeks, 20 regenerants from each explant (shoot tip and node) were tested for per cent survival.

The plantlets used to assess clonal fidelity were obtained from a single seedling which served as the mother plant (Mo). Genomic DNA was isolated 
from the leaves of 12 randomly selected micropropagated plants and the Mo using the standard CTAB method (Doyle and Doyle 1990). A total of 40 random decamer primers (Operon Technologies, Almeda, USA) were used for RAPD analysis, out of which 18 were selected on the basis of reproducibility of bands. RAPD amplification was carried out in $20 \mu \mathrm{l}$ reaction volume containing $25 \mathrm{ng}$ DNA, 1× PCR buffer (Bangalore Genei, India), $200 \mu \mathrm{M}$ dNTPs (Bangalore Genei, India), $0.8 \mu \mathrm{M}$ of RAPD primer, $0.3 \mu \mathrm{l}$ of Taq DNA polymerase (Bangalore Genei, India) in a thermal cycler (BioRad, UK). PCR amplification conditions were an initial denaturation at $94^{\circ} \mathrm{C}$ for 4 min followed by 39 cycles of denaturation at $92^{\circ} \mathrm{C}$ for $30 \mathrm{~s}$, annealing at $37^{\circ} \mathrm{C}$ for $45 \mathrm{~s}$, extension at $72^{\circ} \mathrm{C}$ for $2 \mathrm{~min}$ and a final extension at $72^{\circ} \mathrm{C}$ for $7 \mathrm{~min}$. The PCR products were separated on $1.5 \%$ agarose (Himedia, India) gel through electrophoresis using $100 \mathrm{bp}$ and $1 \mathrm{~kb}$ ladder as the band size standard' and photographed using Gel Documentation System (BioRad, UK). RAPD analysis was repeated twice using each primer to establish reproducibility of the banding pattern.

The data on initial explants establishment, shoot bud formation, shoot proliferation and rooting were collected for 4 weeks. All the experiments were repeated thrice and the values were represented as mean \pm standard error. Data were subjected to one-way analysis of variance by Fischer's least significant difference $(p<0.05)$ (Gomez and Gomez 1984). For RAPD analysis, consistent and well-resolved bands were scored manually as ' 1 ' if present and ' 0 ' if absent in the gel.

\section{Results and Discussion}

Both shoot tips and nodal segments were used as initial explants for aseptic establishment of cultures on MS supplemented with various cytokinins. The best initial morphogenic response (6 - 8 shoots/explant) was observed after 15 days when shoot tips and nodal segments were cultured on medium with $\mathrm{Kn}(2 \mathrm{mg} / \mathrm{l})$ (Fig. 1a, Table 1). The degree of growth and differentiation varied considerably with the medium constitution. Significant variation in number of shoots was observed when $\mathrm{Kn}$ was increased to $2 \mathrm{mg} / \mathrm{l}$ and a further increase to $5 \mathrm{mg} / \mathrm{l}$ resulted in reduction of shoots.

Shoot tips and nodal segments excised from the in vitro raised axenic shoots formed on $\mathrm{Kn}(2 \mathrm{mg} / \mathrm{l})$ were also cultured on various concentrations of $\mathrm{Kn}$ (0.5 - 5 $\mathrm{mg} / \mathrm{l})$ for further shoot bud induction. Explants taken from in vitro propagated shoots of E. alba responded better as compared to field explants. Similar, observations were also reported earlier (Dhaka and Kothari 2005).

It was also observed that at various concentrations of cytokinins simultaneous root induction from nodes also occurred which inhibited further shoot 
multiplication. The shoots obtained in the medium with $\mathrm{Kn}(0.5-5 \mathrm{mg} / \mathrm{l})$, showed significant increase in leaf size, internode elongation and stem thickness but at the optimum concentration of kinetin $(2 \mathrm{mg} / \mathrm{l})$ simultaneous rooting was minimized and the increase in leaf size, internode elongation and stem thickness was also negligible. Kinetin was also found to be more effective than BAP for promoting shoot length as reported earlier (Baskaran and Jayabalan 2005) (Table 2).
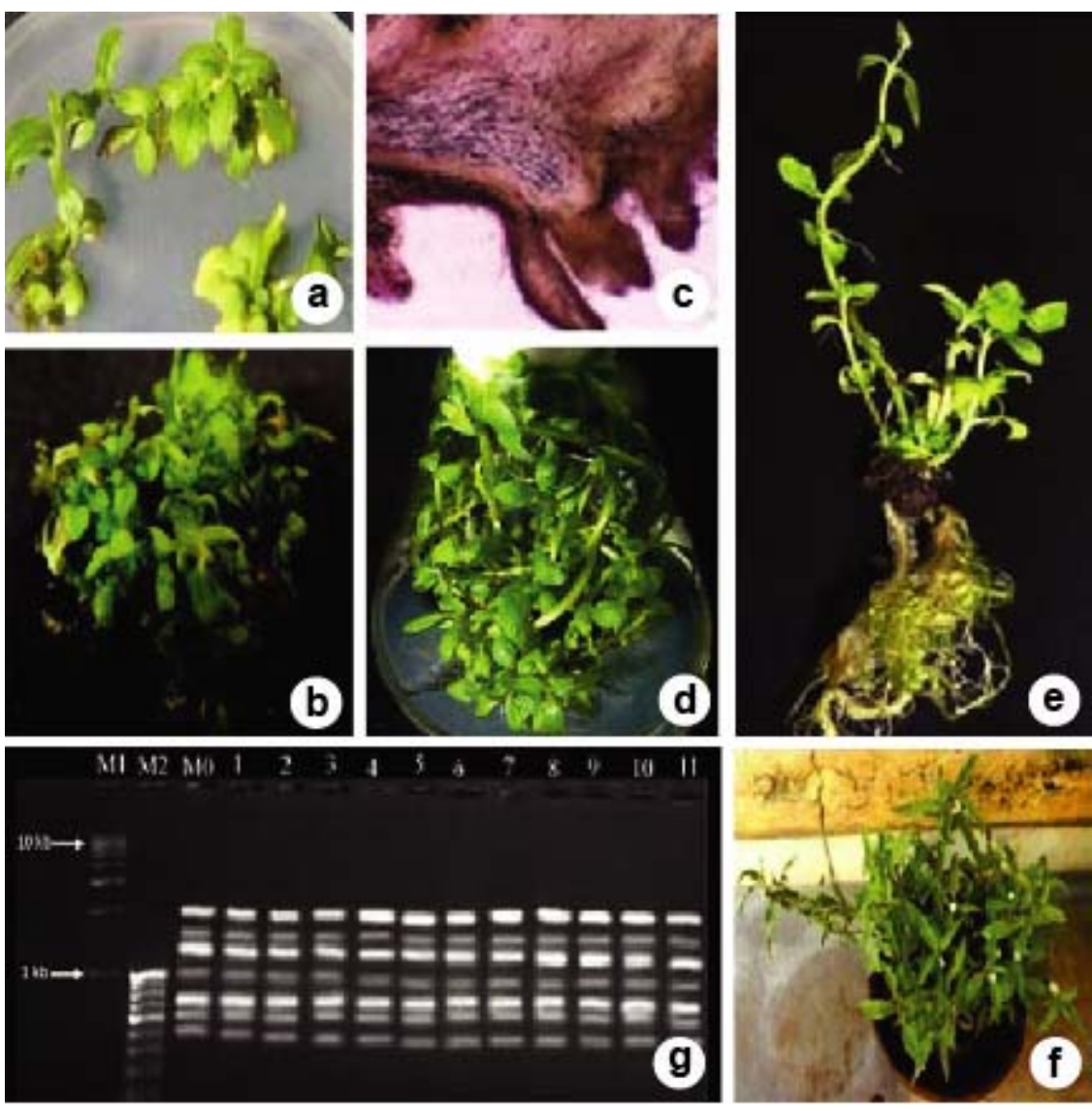

Fig. 1a-g: (a) Direct induction of shoot buds from nodal explants cultured on MS + Kn (2.0 mg/l). (b) Multiplication of shoots from nodal explants cultured on MS + Kn $(2.0 \mathrm{mg} / \mathrm{l})+\mathrm{GA} 3(0.5 \mathrm{mg} / \mathrm{l})$. (c) Adventitious shoot buds in a section. (d) Shoot buds proliferation and elongation from nodal explants cultured on MS + Kn $(2.0 \mathrm{mg} / \mathrm{l})+\mathrm{GA}_{3}\left(0.5 \mathrm{mg} / \mathrm{l}\right.$ wih $1.0 \mu \mathrm{M} \mathrm{CuSO}_{4}$. (e) Rooting on MS supplemented with IBA $(1.0 \mathrm{mg} / \mathrm{l})$. (f) Field transferred plants. (g) RAPD profile of regenerated plantlets (Primer-OPF10) (Lanes: M1 and M2 = Molecular weight markers, Mo = mother plant, 1 $11=$ In vitro regenerated plantlets.

For shoot proliferation, shoot bud induced from shoot tip and nodal explants on $\mathrm{Kn}(2 \mathrm{mg} / \mathrm{l})$ was sectored into clumps (2 - 3 shoots each) and subcultured on the medium containing $\mathrm{Kn} / \mathrm{BAP}$ in combination with $\mathrm{GA}_{3}(0.5 \mathrm{mg} / \mathrm{l})$ at an 
Table 1. Effect of cytokinins on shoot bud induction from shoot tips and nodal explants of Eclipta alba.

\begin{tabular}{lccccc}
\hline \multirow{2}{*}{ Cytokinin } & $\begin{array}{c}\text { Concentration } \\
(\mathrm{mg} / \mathrm{l})\end{array}$ & \multicolumn{2}{c}{ Shoot tip } & \multicolumn{2}{c}{ Nodal segment } \\
\cline { 3 - 6 } & 0.5 & 100 & $4.6 \pm 0.3^{\mathrm{d}}$ & 80 & $5.2 \pm 0.3^{\mathrm{e}}$ \\
\hline BAP & 1.0 & 100 & $5.2 \pm 0.3^{\mathrm{f}}$ & 100 & $5.4 \pm 0.2^{\mathrm{e}}$ \\
& 2.0 & 100 & $4.8 \pm 0.3^{\mathrm{de}}$ & 100 & $6.0 \pm 0.4^{\mathrm{f}}$ \\
& 3.0 & 80 & $4.4 \pm 0.4^{\mathrm{cd}}$ & 100 & $5.4 \pm 0.5^{\mathrm{e}}$ \\
& 5.0 & 80 & $3.8 \pm 0.3^{\mathrm{b}}$ & 80 & $4.4 \pm 0.4^{\mathrm{d}}$ \\
& 0.5 & 95 & $4.4 \pm 0.8^{\mathrm{cd}}$ & 100 & $6.0 \pm 0.4^{\mathrm{f}}$ \\
Kn & 100 & $5.2 \pm 0.4^{\mathrm{f}}$ & 100 & $6.4 \pm 0.5^{\mathrm{g}}$ \\
& 1.0 & 100 & $6.6 \pm 0.5^{\mathrm{h}}$ & 100 & $7.6 \pm 0.4^{\mathrm{i}}$ \\
& 2.0 & 100 & $6.4 \pm 0.5^{\mathrm{g}}$ & 90 & $7.2 \pm 0.3^{\mathrm{h}}$ \\
& 3.0 & 90 & $4.2 \pm 0.8^{\mathrm{c}}$ & 90 & $6.4 \pm 0.3^{\mathrm{g}}$ \\
& 5.0 & 85 & $3.4 \pm 0.5^{\mathrm{a}}$ & 90 & $3.6 \pm 0.2^{\mathrm{b}}$ \\
TDZ & 90 & $3.8 \pm 0.4^{\mathrm{b}}$ & 90 & $4.0 \pm 0.3^{\mathrm{c}}$ \\
& 0.1 & 95 & $4.2 \pm 0.8^{\mathrm{c}}$ & 100 & $3.8 \pm 0.4^{\mathrm{bc}}$ \\
& 0.2 & 80 & $3.2 \pm 0.4^{\mathrm{a}}$ & 95 & $3.6 \pm 0.5^{\mathrm{b}}$ \\
& 0.5 & 80 & $3.2 \pm 0.8^{\mathrm{a}}$ & 90 & $3.0 \pm 0.4^{\mathrm{a}}$ \\
\hline
\end{tabular}

Means ( \pm SE) within a column followed by different letters are significantly different according to Fischer's LSD $\mathrm{p}<0.05$.

Table 2. Effect of adding $\mathrm{GA}_{3}$ in combination with cytokinins on shoot proliferation and elongation from cultured shoot tips and nodal explants of E. alba.

\begin{tabular}{|c|c|c|c|c|c|c|c|}
\hline \multicolumn{2}{|c|}{$\begin{array}{c}\text { Growth } \\
\text { regulators }(\mathrm{mg} / \mathrm{l})\end{array}$} & \multicolumn{2}{|c|}{$\begin{array}{l}\text { Percentage } \\
\text { response }\end{array}$} & \multicolumn{2}{|c|}{$\begin{array}{l}\text { No. of shoot buds } \\
\text { elongated }(>2 \mathrm{~cm})\end{array}$} & \multicolumn{2}{|c|}{$\begin{array}{l}\text { Shoot buds } \\
\text { mean } \pm \text { SE }\end{array}$} \\
\hline $\mathrm{GA}_{3}$ & BAP & Shoot tip & Node & Shoot tip & Node & Shoot tip & Node \\
\hline 0.5 & 0.5 & 80 & 100 & 2 & 2 & $5.2 \pm 0.3^{a}$ & $6.2 \pm 0.3^{c}$ \\
\hline 0.5 & 1.0 & 100 & 100 & 2 & 3 & $5.6 \pm 0.2^{b}$ & $7.8 \pm 0.3^{\mathrm{d}}$ \\
\hline 0.5 & 2.0 & 100 & 100 & 2 & 3 & $8.2 \pm 0.3^{e}$ & $8.4 \pm 0.2^{\mathrm{e}}$ \\
\hline 0.5 & 3.0 & 90 & 90 & 3 & 2 & $6.2 \pm 0.3^{c}$ & $5.8 \pm 0.3^{b}$ \\
\hline 0.5 & 5.0 & 90 & 80 & 2 & 2 & $5.4 \pm 0.2^{\mathrm{ab}}$ & $5.6 \pm 0.4^{b}$ \\
\hline $\mathrm{GA}_{3}$ & $\mathrm{Kn}$ & & & & & & \\
\hline 0.5 & 0.5 & 90 & 90 & 2 & 3 & $7.8 \pm 0.3^{d}$ & $8.4 \pm 0.3^{e}$ \\
\hline 0.5 & 1.0 & 100 & 100 & 3 & 4 & $8.2 \pm 0.3^{e}$ & $8.8 \pm 0.2^{\mathrm{f}}$ \\
\hline 0.5 & 2.0 & 100 & 100 & 4 & 5 & $10.6 \pm 0.2^{g}$ & $12.4 \pm 0.3^{\mathrm{h}}$ \\
\hline 0.5 & 3.0 & 100 & 100 & 3 & 5 & $8.8 \pm 0.3^{f}$ & $9.8 \pm 0.3 \mathrm{~g}$ \\
\hline 0.5 & 5.0 & 95 & 100 & 2 & 3 & $6.0 \pm 0.3^{c}$ & $5.0 \pm 0.4^{\mathrm{a}}$ \\
\hline
\end{tabular}

Means $( \pm$ SE) within a column followed by different letters are significantly different according to Fischer's LSD $\mathrm{p}<0.05$.

interval of 10 - 15 days. Best proliferation and elongation of shoots was achieved on medium containing $\mathrm{Kn}(2 \mathrm{mg} / \mathrm{l})$ and $\mathrm{GA}_{3}(0.5 \mathrm{mg} / \mathrm{l})$ where 30 - 40 shoots were formed from each explants after 3 passages. Without $\mathrm{GA}_{3}$, retarded shoot growth 
was observed which depicts the significance of GA3 in shoot proliferation and elongation as reported for other plants (Dhaka and Kothari 2002). Continuous shoot proliferation could also be sustained through subcultures for consequent 3 years as also reported earlier (Dhaka and Kothari 2005).

For every micropropagation protocol, successful rooting of microshoots is a prerequisite to facilitate their establishment in soil and to sustain their field survival. In vitro raised shoots $(>2 \mathrm{~cm})$ were excised from the cluster and transferred to MS (half-strength or full-strength) supplemented variety of auxins for rooting. Best rooting response $(100 \%)$ was observed on full strength MS supplemented with IBA (1.0 mg/l) (Fig 1e). Similar response was observed by Dhaka and Kothari (2005). IBA is the most commonly used auxin for root formation not only in herbs but also from shoots of woody trees (Goyal et al. 2012). Multiple roots (average 3 - $5 \mathrm{~cm}$ in length) developed in 2 - 3 weeks. At higher concentration of IBA the percentage of rooting decreased and callus formation occurred at basal cut end as also reported by Goyal et al. (2012). A low survival frequency was observed when rooted plants were directly transferred from agar containing medium to soil (Dangi et al. 2012). Yu et al. (2000) suggested that aeration was an important factor in the formation of adventitious roots. Therefore, plantlets with well developed root system were washed gently with running tap water to remove the traces of agar and then transferred to porous thermocol pots containing autoclaved garden soil, farmyard manure and sand $(2: 1: 1)$ and regularly irrigated with one-eighth strength MS basal salt solution devoid of sucrose every 4 th day for 2 weeks. Similar approach was also reported earlier (Baskaran and Jayabalan 2005). The potted plantlets were covered with porous polyethylene bags for maintaining high humidity and kept inside the controlled culture room conditions. The relative humidity was gradually reduced, and after a month the plantlets were transplanted to field conditions where $80 \%$ of the micropropagated plantlets after attaining full maturity flowered normally (Fig. 1f).

The regeneration potential of plants is known to be influenced by extrinsic supply of nutrients in the tissue culture media. Inorganic nutrients are essential components of MS and hence offer to be the best variable to study their effect on the morphogenic potential of the plant under study (Kothari et al. 2008). They act as secondary messengers and help in regulating and controlling plant tissue growth (Niedz and Evens 2007).

Realizing the significance of inorganic micronutrients in plant regeneration, effect of eight micronutrients $\left(\mathrm{H}_{3} \mathrm{BO}_{3}, \mathrm{ZnSO}_{4}, \mathrm{CuSO}_{4}, \mathrm{CoCl}_{2}, \mathrm{Fe}-\mathrm{EDTA}, \mathrm{Na}_{2} \mathrm{MoO}_{4}\right.$, $\mathrm{MnSO}_{4}$ and $\mathrm{KI}$ ) was studied on shoot bud induction and proliferation (Figs 2,3). Reduction in the regeneration capacity of shoot tips and nodal explants was 
observed in response to increasing concentration of $\mathrm{Zn}, \mathrm{I}, \mathrm{Fe}$ and $\mathrm{Bo}$, while an increase in concentration of $\mathrm{Cu}, \mathrm{Mb}, \mathrm{Mn}$, and $\mathrm{Co}$ in $\mathrm{MS}$ showed improved regeneration response initially up to a threshold beyond which there was decline (Fig. 2). When the concentration of $\mathrm{CuSO}_{4}$ was increased $(1 \mu \mathrm{M})$, a maximum of
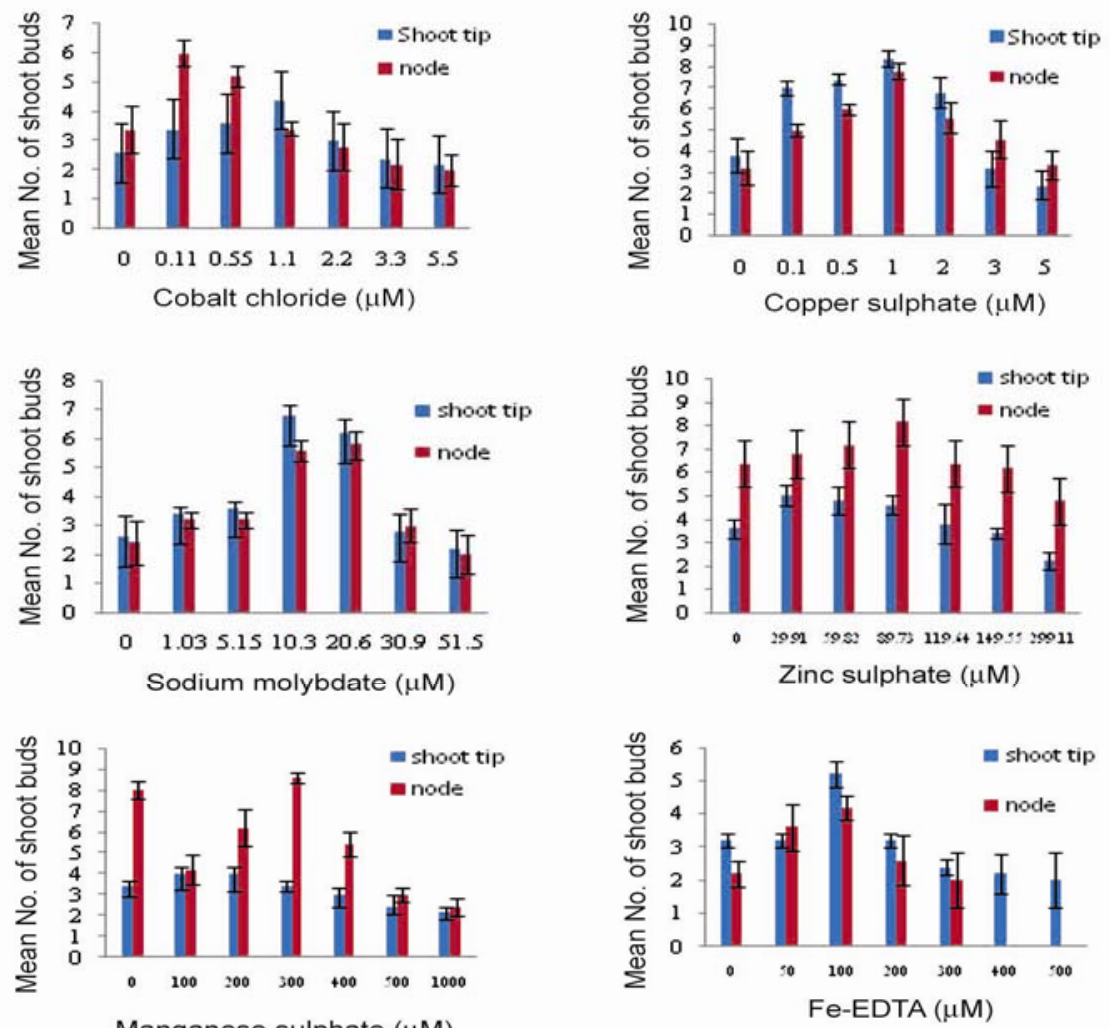

Manganese sulphate $(\mu \mathrm{M})$
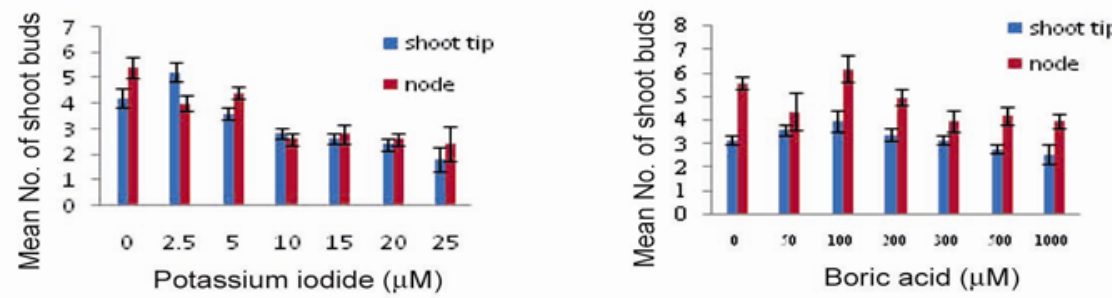

Fig. 2. Effect of different concentrations of inorganic miconutrients on shoot bud induction from shoot tip and nodal explants of Eclipta alba. (a) cobalt chloride, (b) copper sulphate, (c) sodium molybdate, (d) zinc sulphat, (e) manganese sulphate, (f) Fe-EDTA, (g) potassium iodide, (h) boric acid.

16 - 17 shoot buds were formed from shoot tips and nodal explants (Figs 1d, 3). Shoots formed on the medium devoid of copper were pale green. Copper is an essential component of several enzymes involved in electron transport, protein, 
and carbohydrate synthesis (Kothari et al. 2008). Increase in the regeneration response in the presence of elevated levels of copper was also reported by several workers in various plants (Joshi and Kothari 2007, Kothari et al. 2008, KhuranaKaul et al. 2010). A maximum of 13 shoots were formed on medium with 0.55 $\mathrm{CoCl}_{2} \mu \mathrm{M}$ when nodal segments were used as an explant as compared to 9 shoots on medium with the basal concentration of cobalt (Figs 2a, 3). Increased $\mathrm{CoCl}_{2}$ has been shown to greatly improve regeneration in other plant species also (Dangi et al. 2012). $\mathrm{Co}^{2+}$ inhibits ethylene production by blocking the conversion of 1-aminocyclopropane-1-carboxylic acid to ethylene (Yang and Hoffman 1984). Thus, the enhancement of shoot regeneration with increased $\mathrm{Co}^{2+}$ is hypothesized to be due to a decrease in the level of ethylene (Dangi et al. 2012). Zinc is essential for protein synthesis, IAA synthesis and nitrogen metabolism but it is toxic at high levels and produces adverse effects on plant growth and development (Wang et al. 2009). The number of shoot buds formed from shoot tip and nodal explants increased initially when the concentration of $\mathrm{Zn}$ was less but at higher $\mathrm{Zn}$ levels number of shoot buds formed in vitro decreased (Fig. 2d). A maximum of 14 shoots were formed when nodal segments were cultured on basal MS concentration of $\mathrm{Zn}$ in the medium. However, Ghnaya et al. (2010) reported that elevation in amino acid and carbohydrate (glucose and sucrose) content of in vitro cultured plantlets occur due to concomitant zinc variation in culture medium. The $2 \mathrm{x} \mathrm{Mn}$ concentration was the best for regeneration in case of Paspalum (Kothari et al. 2008). Similarly, in the present study an improvement of in vitro response has been discerned when manganese concentration was increased to $300 \mu \mathrm{M}$ (Fig. 2e). Sahasrabudhe et al. (1999). found an increase in the embryogenic response of indica rice on higher concentrations of boric acid which is contradictory to the present study where maximum response was observed at basal concentration of boric acid $(100 \mu \mathrm{M})$, when both shoot tips and nodal segments were used as explants (Fig. 2h). It was observed that $100 \mu \mathrm{M} \mathrm{H}_{3} \mathrm{BO}_{3}$ was advantageous for further multiplication and elongation of shoots in both the explants (Fig. 3). Boron is required for normal plant growth and development of all higher plants and considered to be involved in nucleic acid metabolism, carbohydrate and protein metabolism and cell wall synthesis (Sotiropoulos et al. 2006). In plants, iron is mainly bound to chelators and complex compounds. It was observed that absence of iron in culture medium resulted in the formation of pale green leaves. This is attributed mainly due to absence of heme- and iron sulphur-proteins. Best response was observed at basal concentration of iron which is in conformity with the results obtained earlier. Molybdenum is directly involved in reduction of nitrogen as it acts as a cofactor for the proper functioning of two most crucial enzymes in plants; nitogenase and nitrate reductase. Nitrogenase is needed for nitrogen fixation and nitrate reductase 
reduces nitrate to nitrite in nitrogen assimilation process of the plant cell thereby making nitrogen readily available to the plant in usuable form. In this study, best response was observed when molybdenum concentration was 10 times the normal MS level in shoot tip explants and 20 times the normal MS level in nodal explants (Fig. 3).

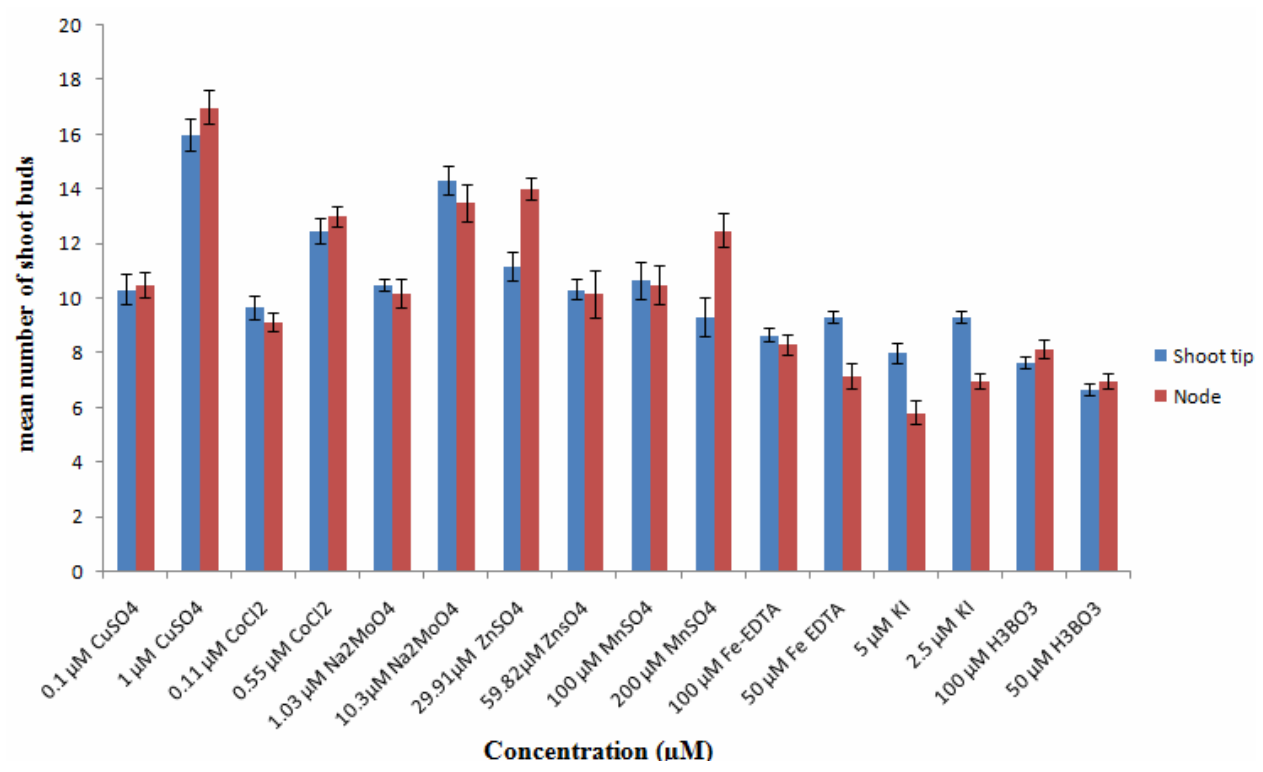

Fig. 3. Effect of different concentrations of inorganic micronutrients on shoot proliferation in Eclipta alba.

The regenerated plants were checked for their stability using RAPD primers. Of the 40 RAPD primers used for preliminary screening of the control plants, only 18 gave clear and distinct scorable bands. These primers were further used for the analysis of the micropropagated plants. The 18 primers generated 83 scorable bands. The number of scorable bands varied from 2 (OPT-01) to 7 (OPF10) with an average of 4.6 bands per primer. The size range for the bands varied from 300 to 3,000 $\mathrm{bp}$. DNA fingerprinting profiles of regenerants revealed that there were no polymorphic DNA fragments and no variation among mother plant and plantlets raised through micropropagation. Comparison of the banding pattern between the mother and micropropagated plants revealed the absence of any polymorphic bands (Fig. 1g), thus, confirming true-to-type nature of regenerated plants. RAPD has been widely used in genetic variation studies in tissue cultured derived plantlets as has been also reported earlier in various plants (Dangi et al. 2012, Goyal et al. 2012). 


\section{Acknowledgment}

Shruti Bardar thanks University Grants Commission (UGC), New Delhi for the award of JRF/SRF.

\section{References}

Baskaran P and Jayabalan N (2005) An efficient micropropagation system for Eclipta alba - A valuable medicinal herb. In Vitro Cell Dev. Biol. - Plant. 41:532-539.

Borthakur M, Dutta K, Nath SC and Singh RS (2000) Micropropagation of Eclipta alba and Eupatorium adenophorum using a single step nodal cutting technique. Plant Cell Tiss. Org. Cult. 62: 239-242.

Dangi B, Kachhwaha S and Kothari SL (2012) Regeneration and Agrobacterium-mediated genetic transformation of Terminalia bellerica Roxb.: A multipurpose tree species. In Vitro Cell Dev. Biol. - Plant 48: 304-312.

Dhaka N and Kothari SL (2002) Phenylacetic acid improves bud elongation and in vitro plant regeneration efficiency in Helianthus annuus L. Plant Cell Rep. 21: 29-34.

Dhaka N and Kothari SL (2005) Micropropagation of Eclipta alba (L.) Hassk - an important medicinal plant. In Vitro Cell Dev. Biol. - Plant 41:658-661.

Doyle JJ and Doyle L J (1990) Isolation of plant DNA from tissue. Focus. 12:13-15.

Franca SC, Bertoni BW and Pereira AMS (1995) Antihepatotoxic agent in micropropagated plantlets of Eclipta alba. Plant Cell Tiss. Org. Cult. 40: 297-299.

Gawde AJ and Paratkar GT (2004) Micropropagation of Eclipta alba Hassk.: An approach to shorten the protocol. Indian J. Biotechnol. 3: 128-132.

Ghnaya AB, Hourmant A, Cerantola S, Kervarec N, Cabon JY, Branchard $M$ and Charles G (2010) Influence of zinc on soluble carbohydrate and free amino acid levels in rapeseed plants regenerated in vitro in the presence of zinc. Plant Cell Tiss. Org. Cult. 102: 191-197.

Gomez KA and Gomez AA (1984) Statistical procedures in agricultural research. Wiley, New York.

Goyal P, Kachhwaha S and Kothari SL (2012) Micropropagation of Pithecellobium dulce (Roxb.) Benth-a multipurpose leguminous tree and assessment of genetic fidelity of micropropagated plants using molecular markers. Physiol Mol. Biol. Plants 18: 169176.

Jadhav VM, Thorat RM, Kadam VJ and Salaskar KP (2009) Chemical composition, Pharmacological activities of Eclipta alba. J. Pharm. Res. 2: 1129-1231.

Joshi A and Kothari SL (2007) High cooper levels in the medium improves shoot bud differentiation and elongation from the cultured cotyledons of Capsicum annuиm L. Plant Cell Tiss. Org. Cult. 88:127-133.

Khurana-Kaul V, Kachhwaha S and Kothari SL (2010) Direct shoot regeneration from leaf explants of Jatropha curcas in response to thidiazuron and high copper contents in the medium. Biol Plant. 54 : 369-372. 
Kothari-Chajer A, Sharma M, Kachhwaha S and Kothari SL (2008) Micronutrient optimization results into highly improved in vitro plant regeneration in kodo (Paspalum scrobiculatum L.) and finger (Eleusine coracana (L.) Gaertn.) millets. Plant Cell Tiss. Org. Cult. 94: 105-112.

Larkin PJ and Scowcroft WR (1981) Somaclonal variation - A novel source of variability from cell cultures for plant improvement. Theor. Appl. Genet. 60:197-214.

Niedz R and Evens TJ (2007) Regulating plant tissue growth by mineral nutrition. In Vitro Cell Dev. Biol. - Plant 43:370-381.

Ray A and Bhattacharya S (2008) An improved micropropagation of Eclipta alba by in vitro priming with chlorocholine chloride. Plant Cell Tiss. Org. Cult. 92:315-319.

Sahasrabudhe NA, Nandi M and Bahulikar RA (1999) Influence of boric acid on somatic embryogenesis of a cytosterile line of indica rice. Plant Cell Tissue Organ Cult. 58: 7375.

Singh SK, Rai MK and Sahoo L (2012) An improved and efficient micropropagation of Eclipta alba through transverse thin cell layer culture and assessment of clonal fidelity using RAPD analysis. Ind. Crops and Prod. 37: 328-333.

Sotiropoulos TE, Dimassi KN and Tsirakoglou V (2006) Effect of boron and methionine on growth and ion content in kiwifruit shoots cultured in vitro. Biol Plant. 50: 300-320.

Wang H, Liu RL and Jin JY (2009) Effect of zinc and soil moisture on photosynthetic rate and chlorophyll fluorescence parameters of maize. Biol. Plant. 53: 191-194.

Yang SF and Hoffman NF (1984) Ethylene biosynthesis and its regulation in higher plants. Ann. Rev. Plant Physiol. 35: 155-189.

Yu TA, Yeh SD, Cheng YH and Yang JS (2000) Efficient rooting for establishment of papaya plantlets by micropropagation. Plant Cell Tiss. Org. Cult. 61: 29-35. 